\title{
Metallotectic Context of the Mineralization of the Tondabo Gold Prospect (Brobo, Center of Côte d'Ivoire, West Africa)
}

\author{
DaÏ Bi Seydou Mathurin1, Ouattara Gbele1, Gnanzou Allou², \\ Koffi Gnammytchet Barthélémy ${ }^{1}$, Coulibaly Inza² \\ ${ }^{1}$ Laboratoire des Géosciences, Cadre de vie, Environnement et Sciences Géographiques, Institut National Polytechnique Félix \\ Houphouët-Boigny, Yamoussoukro, Côte d'Ivoire \\ ${ }^{2}$ Laboratoire de Géologie du Socle et Métallogénie, UFR-STRM, Université Félix Houphouët-Boigny, Yamoussoukro, Côte d’Ivoire \\ Email: gbele.ouattara@yahoo.fr
}

How to cite this paper: Mathurin, D.B.S., Gbele, O., Allou, G., Barthélémy, K.G. and Inza, C. (2020) Metallotectic Context of the Mineralization of the Tondabo Gold Prospect (Brobo, Center of Côte d'Ivoire, West Africa). International Journal of Geosciences, 11, 325-344.

https://doi.org/10.4236/ijg.2020.115017

Received: April 14, 2020

Accepted: May 23, 2020

Published: May 26, 2020

Copyright $\odot 2020$ by author(s) and Scientific Research Publishing Inc. This work is licensed under the Creative Commons Attribution International License (CC BY 4.0).

http://creativecommons.org/licenses/by/4.0/

(c) (i) Open Access

\begin{abstract}
The gold mineralization of the Tondabo prospect, located in the northern part of the Oumé-Toumodi-Fettêkro greenstone belt, is mainly hosted in the rhyodacite and to a lesser extent in the mafic volcanics (volcanic lavas and volcanoclastites). These rocks were affected by a hydrothermal alteration marked by quartz veins and veinlets associated with crystals of carbonates, sericite, epidote and sulfides. This hydrothermal alteration induced a pervasive alteration of the surrounding bodies with silicification, chloritization, carbonation and sericitization of the feldspars. The metalliferous paragenesis contains an abundant pyrite, with rare pyrrhotite and chalcopyrite. This mineralization indicates that the Tondabo gold prospect exhibits lithological control. The mineralized deposits are generally affected by a $\mathrm{S} 1$ schistosity oriented mainly N000- $010^{\circ}$ and minority N040- $050^{\circ}$ with a general dip of $60^{\circ}-80^{\circ}$ to the West; however with rare N-S orientations with a dip of $60^{\circ}-80^{\circ}$ to the East. The drilling intervals show that the highest gold contents are linked to the quartz-carbonates veins and veinlets, which are located in the highly deformed zones, characterizing local shear zones.
\end{abstract}

\section{Keywords}

Gold Mineralization, Rhyodacite, Structures, Hydrothermal Alteration, Tondabo, Côte d'Ivoire

\section{Introduction}

The West African Birimian formations have become one of the preferred targets 
for gold deposits. In fact, in these formations, several mines of more than 10 million ounces in Ghana, Mali, Guinea and Burkina Faso were able to be updated. The geological formations in the study area belong to the Oumé-Toumodi-Fettêkro greenstone belt. They constitute the northern termination of this greenstone belt in which several mines have been discovered in the southern part. The work carried out in the southern part of this greenstone belt by [1] in Bonikro, [2] in Agbahou and [3] Bandama-Dougba, revealed different typologies of sulphides, mineralogical associations and types of gold mineralization in the southern part. Thus, it emerges from these observations, the following problems: Are these gold mineralizations continuous in the northern part? If so, what are their characteristics?

Our work aims to combine lithostructural analysis, alterations and gold analysis results to better identify the characteristics of the Tondabo mineralization.

\section{Geological Setting}

The study region is located in the northern end of the Oumé-Toumodi-Fettêkro greenstone belt and extends to the Comoé sedimentary basin in central Côte d'Ivoire, West Africa (Figure 1) [4] [5].

The department of Brobo is located in the administrative region of Bouaké, about $25 \mathrm{~km}$ from this city on the Bouaké-M'Bahiakro axis. The study area is between longitudes $5^{\circ}$ and $4^{\circ} 20^{\prime} \mathrm{W}$ and latitudes $7^{\circ} 20^{\prime}$ and $7^{\circ} 59^{\prime} \mathrm{N}$. The area covers the localities of Brobo, Tiendiekro, Raviart, Kouassi-Kouassikro, M’Bahiakro, Satama Sokoura and Satama Sokoro. The Tondabo gold prospect is located in the Brobo region.

The Brobo region has several lithological units (Figure 1) [5]. These include various granitoids (two micas granites, biotite granites, granodiorites, gabbros, diorites, gneiss) located to the west and in the central part. The Fettêkro greenstone consists of metavolcanites (especially acid and basic pyroclastites) and metasediments (mica schists, schists, grauwackes, quartzites). All of these formations are bordered by the metasediments of the Comoé basin to the East.

\section{Material and Method}

\subsection{Metallographic Microscopy}

One of the objectives of this study is to define from the metallographic microscope, of the Nachet type, the different paragenesis accompanying the gold mineralization. To characterize the Tondabo mineralization, eleven (11) samples were selected after the results obtained for gold, on the core drill holes in the favorable zones. Thin sections produced were used to define different mineral associations and the reactions (alterations) with the hydrothermal fluid.

\subsection{Survey Sections}

The description of the mineralized zones is based on the high gold values obtained from analyzes. The wells studied come from RC and DD holes drilled on 


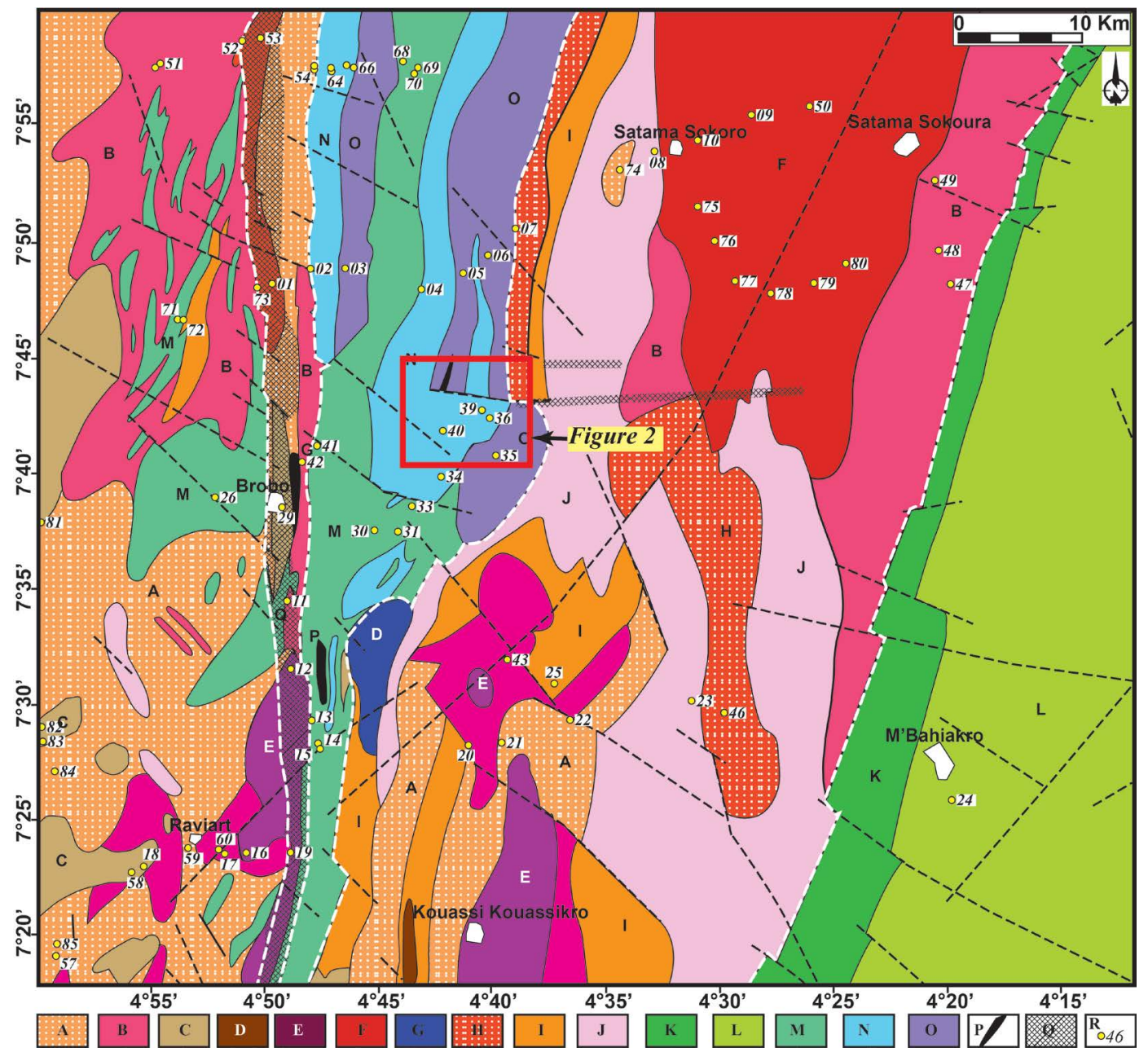

Figure 1. Geological map of M'Bahiakro area [4], modified [5]. A = heterogeneous granite; B = biotite or biotite-amphibole oriented granodiorite; $\mathrm{C}=$ biotite-muscovite granite; $\mathrm{D}=$ biotite-amphibole granodiorite; $\mathrm{E}$ = leucocratic biotite granite; $\mathrm{F}=$ porphyroid biotite-amphibole granodiorite; $\mathrm{G}=$ porphyroid oriented granodiorite biotite-amphibole; $\mathrm{H}$ = migmatitic gneiss; $\mathrm{I}=$ migmatitic gneiss; $\mathrm{J}$ = banded migmatite; Comoé series: $\mathrm{K}=$ black shale, grauwacke, sandstone pelite; $\mathrm{L}=$ sandstone, shale sandstone, shale; $\mathrm{M}=$ mica schist; $\mathrm{N}$ = acid lava, pyroclastite, acid tuff, metagrauwacke; $\mathrm{O}=$ pyroclastite, breccia, basic tuff; $\mathrm{P}=$ quartzite; $\mathrm{Q}=$ mylonite; $\mathrm{R}$ = sample.

the Tondabo prospect (Figure 2). The prospect being located in an intensely deformed zone, we relied on the lithostructural analysis in addition to the gold analysis results to better characterize the mineralization. Additional analyzes of other chemical elements were carried out for the DD survey, in order to better establish the paragenesis. The behavior of the mineralized intervals is highlighted in the sections made from Leapfrog Geo 5.1.1 and MapInfo software.

\subsection{Scanning Electron Microscopy (SEM)}

The study using a scanning electron microscope gives details of different types of sulphides and their interactions with the mineral phases.

As part of this work, six (6) polished samples were carefully selected based on their abundance of sulphide minerals and their belonging to mineralized zones, 


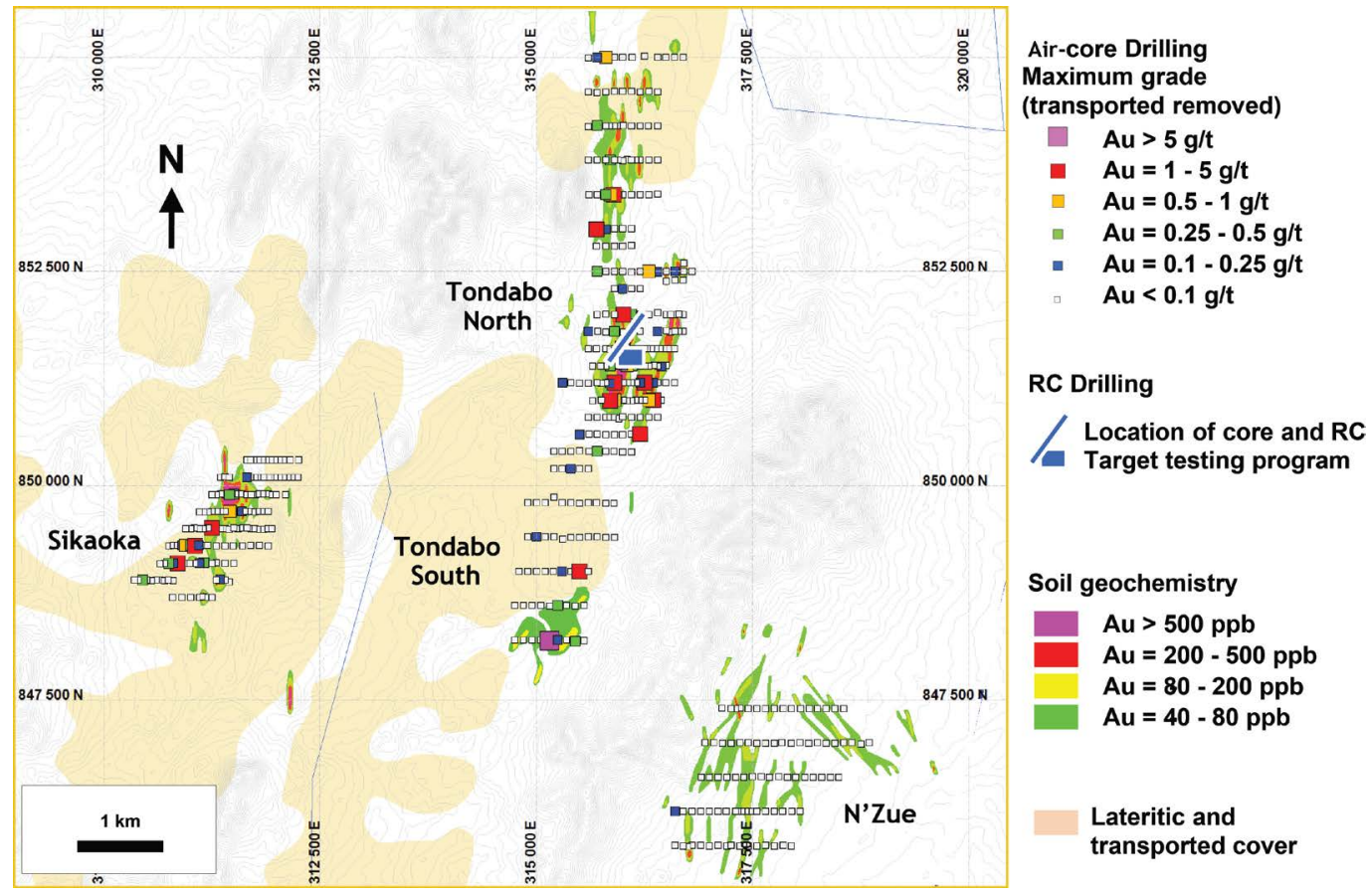

Figure 2. The Tondabo, Sikaoka and N'Zue prospects, modified [6].

and/or affected by hydrothermalism. They went through a scanning electron microscope for the analysis of sulfides, gold and accessory minerals. This study phase allows a better characterization of the metalliferous associations in the mineralized zones and to know their compositions.

\section{Results}

\subsection{Description of Mineralized Zones}

The behavior of the mineralized intervals is highlighted in different sections. Indeed, these sections clearly show that the mineralized zones strongly deformed zones and are found mainly in rhyodacite. The description of these sections is presented as follows:

\section{Section $0 N$}

It was carried out on the basis of three RC drillings and aircore drillings (Figure 3(A)). It shows a contact between the rhyodacite and the mafic volcanics (volcanic lavas and volcanoclastites). Mineralized intercepts have been identified in two holes (BBRC001 and BBRC007). The mineralization is hosted, both in mafic volcanics and in rhyodacite and presents a structural control with a strong foliation superimposed on several types of quartz veins. These zones are, in fact, local deformation corridors. The BBRC001 intercepted $24 \mathrm{~m}$ at $0.71 \mathrm{~g} / \mathrm{t}$ from the $60^{\text {th }}$ meter including $4 \mathrm{~m} @ 1.73 \mathrm{~g} / \mathrm{t}$ from $56 \mathrm{~m}$. The BBRC007 also intercepted $24 \mathrm{~m}$ at $0.53 \mathrm{~g} / \mathrm{t}$ from the $60^{\text {th }}$ meter with high grades which could reach $1.2 \mathrm{~g} / \mathrm{t}$ over almost 4 meters.

\section{Section $+1 N$}

It also includes three deep boreholes. One of which is diamond drilling (BBDD001) and two of the RC type (BBRC005 and BBRC006) in addition to the 

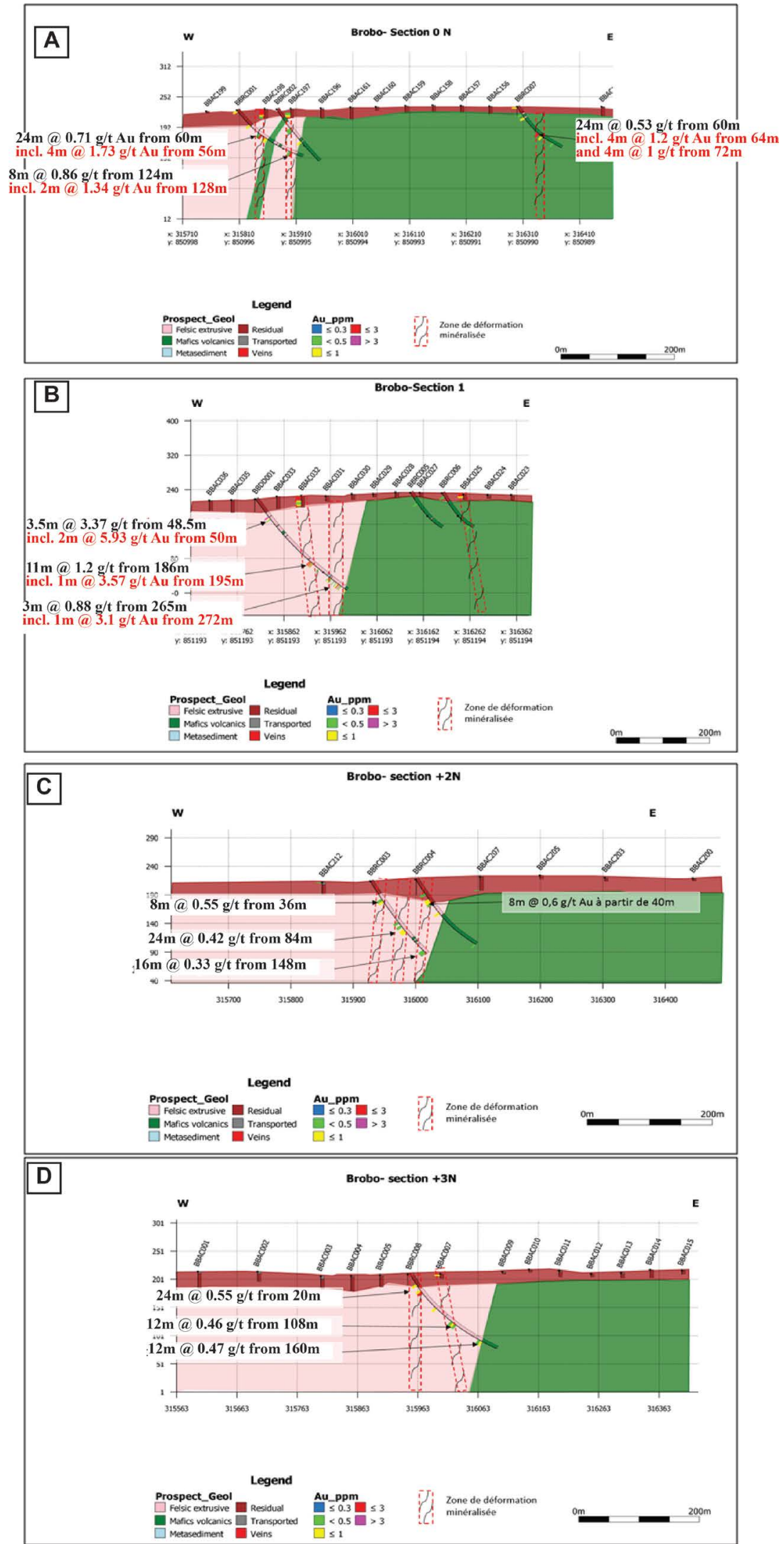

Figure 3. Drilling sections on the Tondabo prospect, modified [6]. (A) Section 0N; (B) Section $+1 \mathrm{~N}$; (C) Section $+2 \mathrm{~N}$; (D) Section $+3 \mathrm{~N}$. 
aircore boreholes (Figure 3(B)). The lithological succession remains the same with rhyodacite in the West and mafic volcanics in the East. Only the diamond drilling intersects three mineralized intervals located in the rhyodacite with respective average grades of $3.37 \mathrm{~g} / \mathrm{t}$ over $3.5 \mathrm{~m}$ from the $48^{\text {th }}$ meter, $1.2 \mathrm{~g} / \mathrm{t}$ over $11 \mathrm{~m}$ from the $186^{\text {th }}$ meter, and the last zone, in contact between mafic volcanics and rhyodacite between 265 and 275.5 meters deep with an average gold content of $0.88 \mathrm{~g} / \mathrm{t}$. The mineralization in these intervals is characterized by silicification and strong sericitization, associated with pyrite which is sometimes disseminated and/or controlled by fractures.

Quartz-carbonates veins form stockworks with alteration halos. These mineralized intervals are materialized by ductile deformation corridors (foliation) having favored circulation and enrichment in hydrothermal fluids.

\section{Section $+2 N$}

It contains two RC boreholes in addition to the aircores (Figure 3(C)). The lithological succession remains the same with in the West the rhyodacite and the mafic volcanics in the East. Regarding the mineralization, three distinct zones could be highlighted in this section with low gold values (approximately $0.3 \mathrm{~g} / \mathrm{t}$ to $0.4 \mathrm{~g} / \mathrm{t}$ ). It is accompanied by silicification, average sericitization, and carbonation (dolomite) and disseminated pyrite. The mineralized zones show a strong foliation with boudinated veins.

\section{Section $+3 N$}

A single RC hole (BBRC006) which intercepted three mineralized zones (Figure $3(D)$ ). The lithology encountered remains the same and the mineralized zones form three bands. The first mineralized interval is located between the 20th and 44th meters deep, with an average grade of $0.55 \mathrm{~g} / \mathrm{t}$. The mineralization is linked to a strong silicification and sericitization, with a weak pyritization. The second mineralized interval is located between the 108th and the 120th meter deep. The mineralization is controlled by quartz veins with strong silicification and carbonation. The last interval having practically the same characteristics in terms of mineralization, is located in contact with the two lithological assemblages (rhyodacite-volcanic mafic). All of these mineralized zones show very strong foliation with boudinated quartz veins.

In general, the gold mineralization remains linked to the ductile deformation corridors which facilitated the circulation of the hydrothermal fluids and the installation of the boudinated quartz veins. The sections present subvertical and subparallel mineralization.

\subsection{Gold Mineralization Host Rocks}

The petrographic study of the drill holes has shown that the most important grades in the Tondabo gold prospect are mainly located in the rhyodacite (Figure 3); although sometimes encountered in mafic volcanics (volcanic lavas and volcanoclastites). Gold mineralization is carried by a system of quartz veins (stockworks), near highly foliated zones. 


\subsection{Mineralization and Deformations}

In the Tondabo prospect, the DD survey (Figure 4) shows that the host rocks of the mineralization are very deformed and generally affected by a $S 1$ foliation oriented mainly N000- $010^{\circ}$ and minority N040- $050^{\circ}$ with a general dip of $60^{\circ}$ $80^{\circ}$ to the West. However, there are rare, generally N-S orientations with a dip of $60^{\circ}-80^{\circ}$ to the East (Figure 5).

In these tectonic zones, the mineralization, carried by the rhyodacite, is associated with a system of quartz veins whose boudinated veins are parallel to the foliation, transverse veins crusscutting foliation and late planar veins, generally subparallel intersecting the foliation. These last veins are those which carry the mineralization.

Highly deformed area with silica and sericite alteration, quartz veins (5\%) and pyrite (2\%)

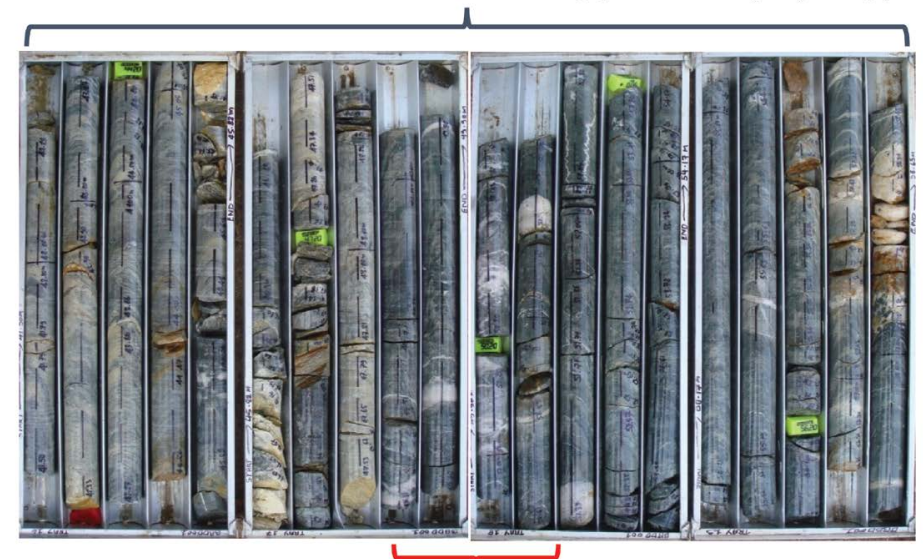

Mineralized zone (48.5 - 52m): stockwork, silicification, sericitization and pyritization

Figure 4. Mineralized zone and associated foliation in hole BBDD001.

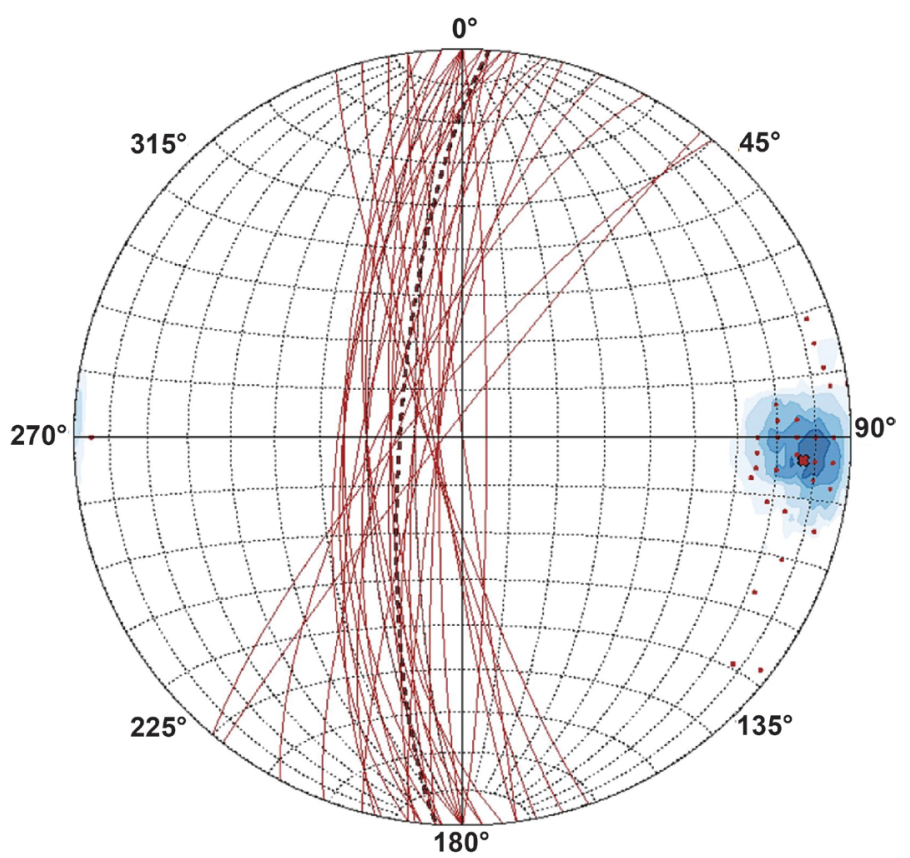

Figure 5. Stereogram of foliation $(n=53)$ associated with mineralization in BBDD001. 
Indeed, the foliation observed could be linked to the general NW-SE compression-transpression phase which allowed the formation of large NE-SW structures. A second deformation phase can be observed in the mineralized zones through hydrothermal brecciation and stockworks with strong silicification (Figure 4). To this is added a series of late veins of subparallel quartz-carbonates, crosscutting the whole. This system of subparallel quartz-carbonates veins seems to carry gold mineralization. The walls of these veins are severely altered, creating a hydrothermal alteration halo.

\subsection{Hydrothermal Alteration and Mineralization}

All veins are also generally associated with partially altered plagioclase crystals and transformed into carbonates (calcite, dolomite), sericite and epidote, silica, pyrite, pyrrhotite, chalcopyrite and ferro-titan oxides (Figure 6).

The mineralized zone sometimes shows two generations of pyritization:

1) The first is marked by cubic pyrites disseminated in the rocks and seems to be contemporaneous with foliation and is not associated with mineralization (Figure 6(A)).

2) The second, more recent phase of pyritization, is associated to quartz veins and an alteration in silica-sericite-carbonates, would have brought mineralization (Figure 6(B)). These pyrites are controlled by quartz-carbonates veins and fractures which crosscutting old structures (veins and foliation). Gold mineralization, however, appears to be associated with this recent pyritization.
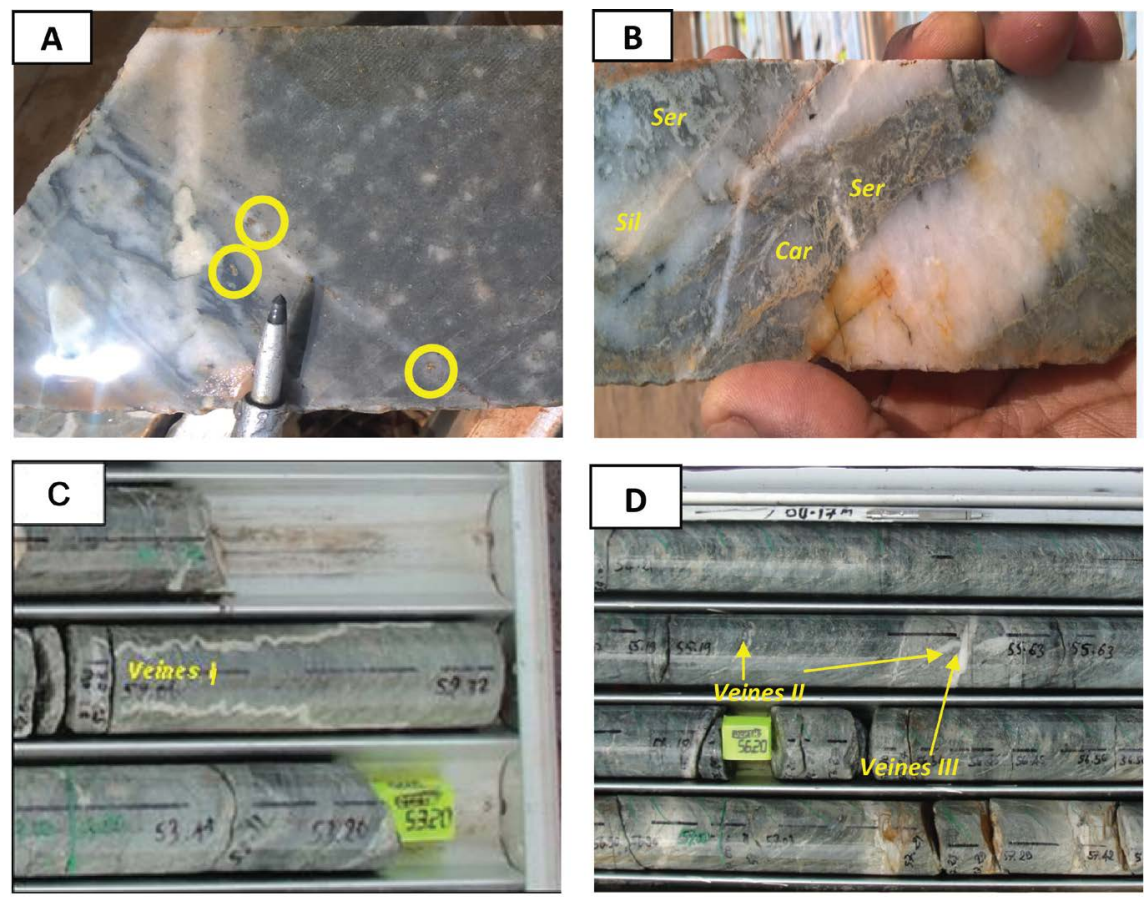

Figure 6. Macroscopic aspects of the veins. (A) Boudinated veins creating a sulphide alteration halo; (B) Quartz-carbonates veins with sulphides (Ser = sericitization, Car $=$ carbonation, Sil = silicification); (C) and (D) Micro folded planar veins (veins I) and planar veins subparallel to foliation (veins II) and late veins (veins III). 
Hydrothermal alteration developed in the corridors with a halo, create distal and proximal zones with respect to the mineralization. The hydrothermal alteration is mainly materialized by a system of generally mineralized veins which are of three types (Figure 6(C) and Figure 6(D)). We have chronologically: i) the transverse veins, filled with quartz-carbonates, which crosscut the foliation and are subparallel to the direction of drilling; ii) the planar veins subparallel to each other and to the foliation, are made up of milky white quartz and carbonates at the wall; iii) the late planar veins milky-white quartz and carbonates crosscutting the whole (veins i, ii and foliation). They are generally associated with sericite, epidote, sulfides (pyrite, pyrrhotite, chalcopyrite) and ferrotitan oxides. This alteration, mainly marked by carbonation (calcite, dolomite), sericitization and mainly brittle silicification; and minority chloritization, epididization and hematization is described as follows:

\section{Carbonation}

It is the most common alteration in the study area (Figure $7(\mathrm{~A})$ and Figure 7(B)). It intensifies as we approach the mineralized zone. This carbonation has a general pervasive character, but can sometimes be observed at the wall of the veins, forming quartz-carbonates veins. Observations in thin sections show that
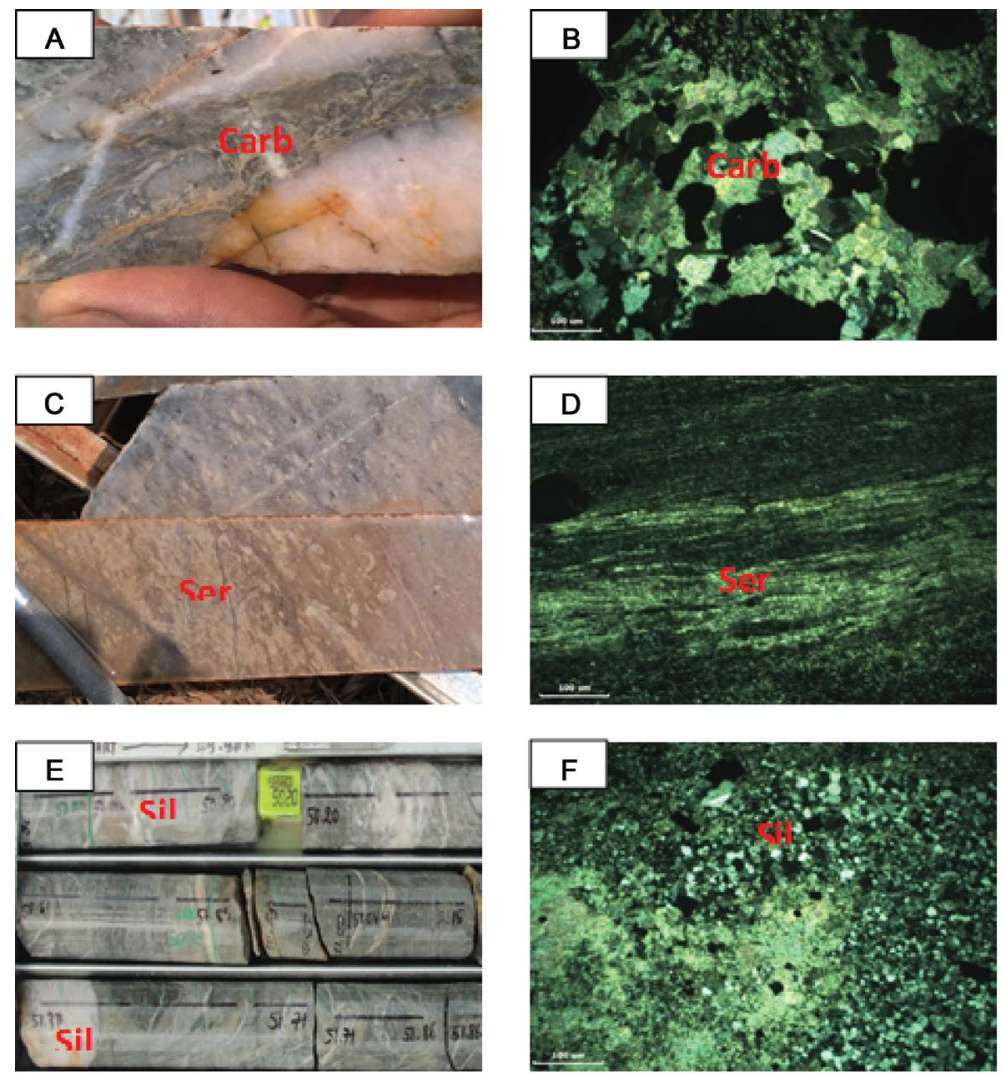

Figure 7. Macroscopic and microscopic aspects of the various alterations (this work). (A), (B): Macroscopic and microscopic aspects of carbonation; (C), (D): Macroscopic and microscopic aspects of sericitization; (E)-(F): Macroscopic and microscopic aspects of silicification $(\mathrm{Carb}=$ carbonation, $\mathrm{Pyr}=$ pyrite, $\mathrm{Ser}=$ sericitization, $\mathrm{Chl}=$ chloritization, $\mathrm{Sil}=$ silicification). 
feldspars are partially and/or completely altered and transformed into carbonates. In SEM, this carbonation shows peaks for high percentage of $\mathrm{CaCO}_{3}$ (more than 50\%) (Figure 8(B)).
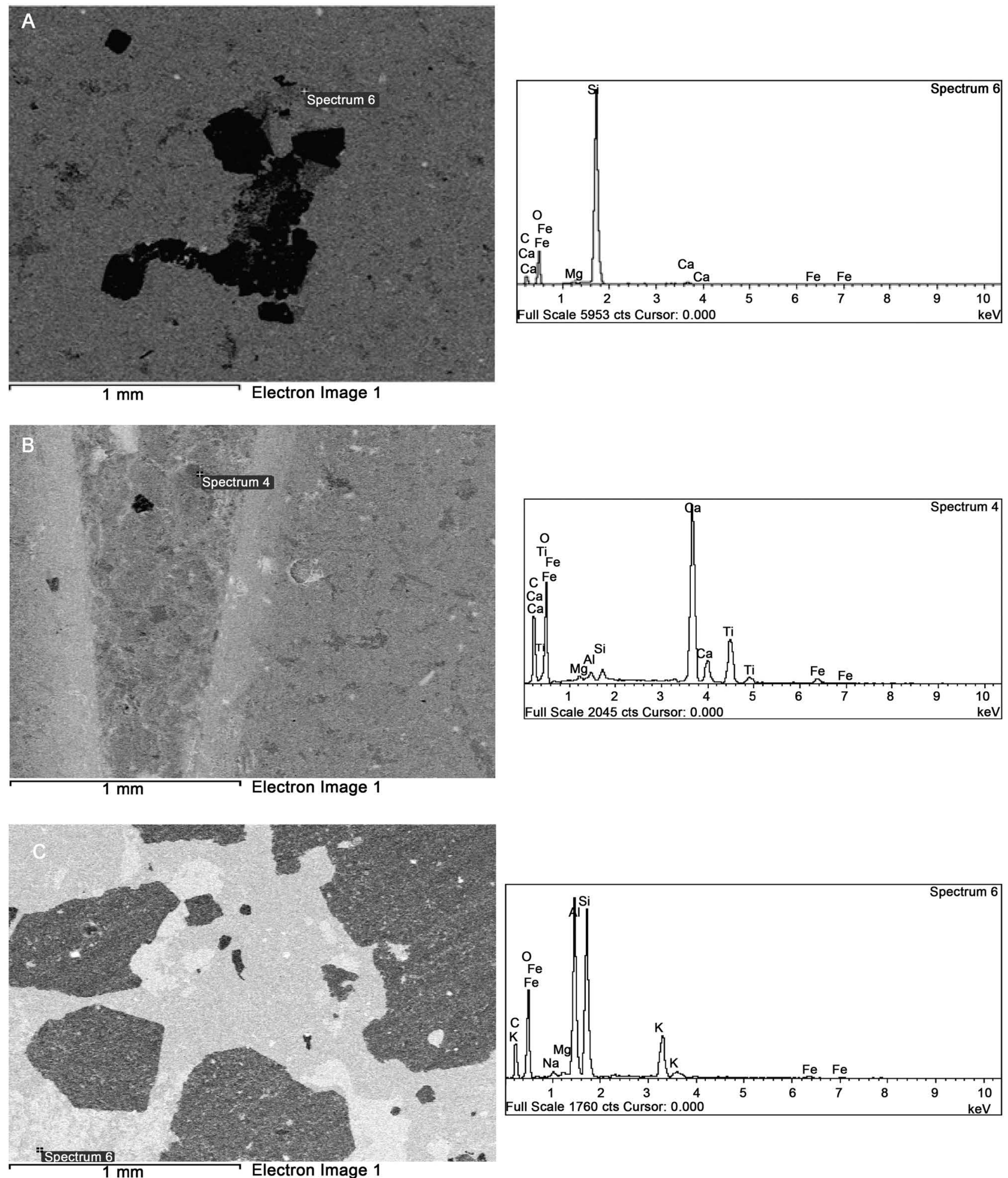

Figure 8. Microscopic aspects and spectra of various alterations from SEM analyzes (this work). (A) Silification; (B) Carbonation; (C) Sericitization. 


\section{Silicification}

It affects all lithologies but it is more marked in the rhyodacites (Figure 8(E) and Figure $8(\mathrm{~F})$ ). It is brittle and enriched in metals. This strong silicification always accompanies gold mineralization. In SEM, silicification is mainly around sulphides with a peak in the spectrum for $\mathrm{SiO}_{2}$ (Figure 8(A)).

\section{Sericitization}

It is also widespread as is carbonation (Figure 7(C) and Figure 7(D)). It is very intense in the areas crossed by the veins and at the walls of the veins. This alteration is more marked in rhyodacites. It is mainly carried by plagioclase. In the mineralized zone, sericitization becomes most often intense, thus causing the formation of bands crosscutting the rock and most often associated with sulphides. Analyzed with SEM, the sericite spectrum shows peaks for the composition of $\mathrm{Al}_{2} \mathrm{O}_{3}, \mathrm{SiO}_{2}$ and $\mathrm{O}_{2}$; then an average $\mathrm{K}_{2} \mathrm{O}$ composition (Figure $8(\mathrm{C})$ ).

\section{Chloritization}

It is generally observed in mafic enclosures, most often in foliation planes. This pervasive alteration, observed on the crystals of biotite, pyroxenes and amphiboles is mainly induced by the general metamorphism of green schist facies.

\section{Epidotization}

It affects all lithologies by destabilization of the crystals of pyroxenes, amphiboles and feldspars. They are often observed in the quartz-feldspathic veins in the mineralized zone.

\section{Hematization}

It is rarely observed in lithologies in the study area.

\subsection{Metalliferous Paragenesis and Typology of the Mineralization}

The sections of RC and DD drilling carried out on the Tondabo prospect show, in places, high gold grades. Despite these results, we didn't observe visible gold. It would be associated with sulfides (pyrite, pyrrhotite and chalcopyrite) present in the quartzo-feldspathic veins. However, hematite is seen a few times.

The analyses carried out at the SEM made it possible to establish the metalliferous paragenesis of the mineralization. The result is an abundance of pyrite as the main sulphide $\left(\mathrm{FeS}_{2}\right)$, sometimes associated with pyrrhotite ( $\mathrm{FeS}$ ). Rare chalcopyrite $\left(\mathrm{CuFeS}_{2}\right)$ remains disseminated in the rock. The mineralization remains associated with the zones of high deformation and circulation of hydrothermal fluids.

\section{Pyrite}

Pyrite is generally automorphic, disseminated in the rock and sometimes deformed: it is the primary pyrite (Figure $9(\mathrm{~A})$, Figure $9(\mathrm{C})$, Figure $9(\mathrm{E})$ ). To this is added a secondary pyritization controlled by the quartzo-feldspathic veins and which accompanies the gold mineralization (Figure 9(B), Figure 9(D), Figure 9(F)). The secondary pyrite is subautomorphic or amorphous. Analysis by SEM (Table 1), these pyrites are generally associated with $\mathrm{CaCO}_{3}, \mathrm{Ca}, \mathrm{Na}, \mathrm{Si}, \mathrm{Al}, \mathrm{K}$, $\mathrm{Mg}$, Dy and Zr. 

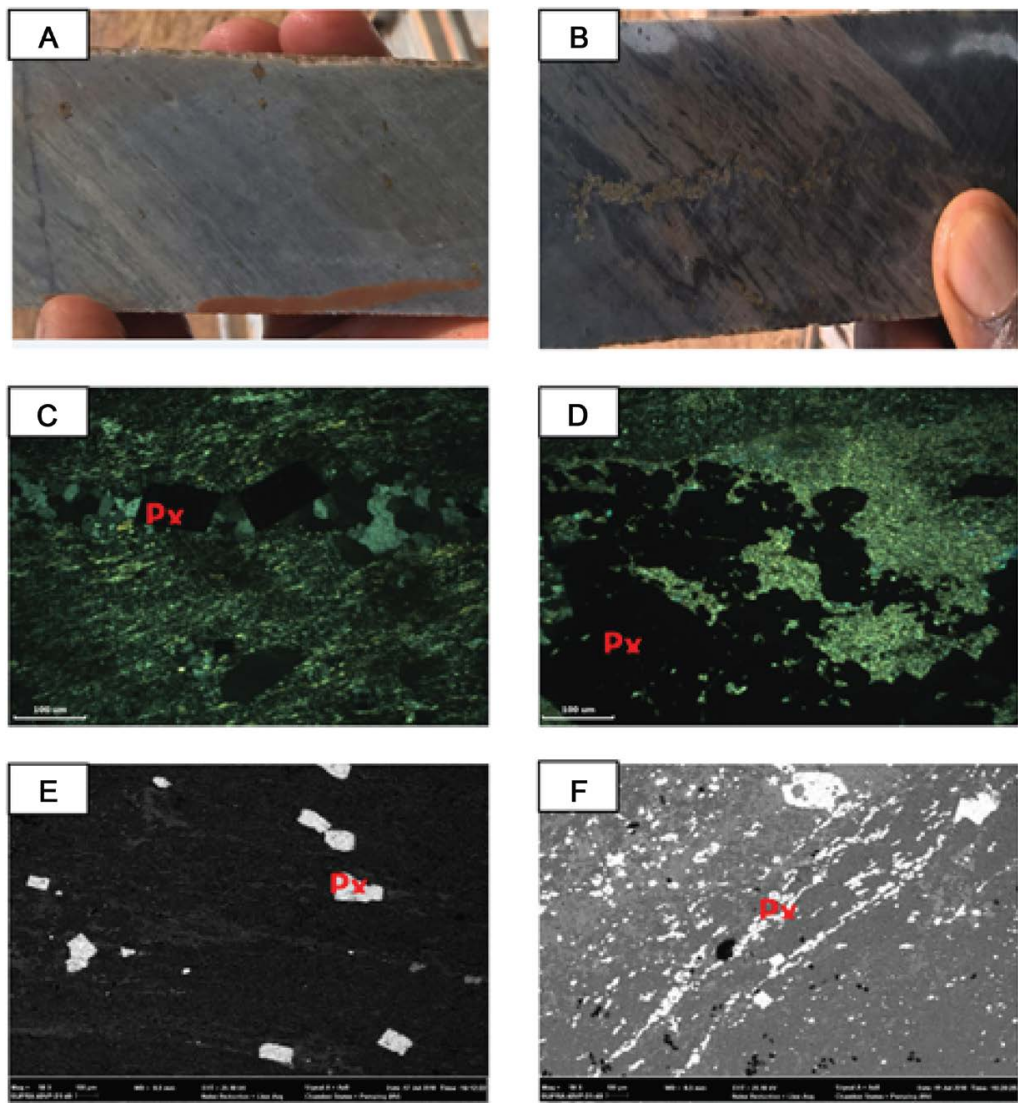

Figure 9. Macroscopic and microscopic aspects of primary and secondary pyrites (this work). (A)-(B): Macroscopic aspect of primary (A) and secondary (B) pyrites. (C)-(D): Polarizing microscope image of primary $(C)$ and secondary pyrites (D). (E)-(F): SEM image of primary (E) and secondary pyrites (F).

\section{Pyrrhotite}

Pyrrhotites are the most abundant sulfides after pyrites. They are distinguished by their bronze yellow color. Pyrrhotite appears as small minerals, generally xenomorphic, and disseminated with sometimes near the pyrite (Figure 10). The SEM analysis (Table 1) shows that these pyrrhotites are associated with $\mathrm{CaCO}_{3}$, $\mathrm{Ca}, \mathrm{Na}, \mathrm{Al}, \mathrm{K}, \mathrm{Dy}$ and Fr.

\section{Chalcopyrite}

Chalcopyrite appears as inclusions in pyrrhotite. It is rarely observed in the drilling sections. It is generally associated with $\mathrm{CaCO}_{3}, \mathrm{Na}, \mathrm{Al}, \mathrm{Zn}$, $\mathrm{Ta}$ and $\mathrm{Dy}$ (Table 1).

\section{Discussion}

In the Tondabo prospect, we have distinguished two types of mineralization:

1) Disseminated mineralization by the distribution of sulphides and other precious metals in the rock. Chemical analyzes show that gold contents can reach $0.5 \mathrm{~g} / \mathrm{t}$. However, it should be noted that this type of mineralization remains very proximal to veins. It could appear to be an injection of fluids into the host rocks;

2) And a more widespread vein mineralization, in which sulphides and other 
precious metals are crack fillings, witnesses to hydrothermal alteration. Gold analyzes have shown grades of up to $2.5 \mathrm{~g} / \mathrm{t}$.

In general, the gold mineralization of the Tondabo prospect has, like other mineralizations in the Birimian, characteristics that define its typology.

Table 1. Summary of SEM analyzes of sulphides (this work).

\begin{tabular}{|c|c|c|c|c|c|c|}
\hline \multirow{2}{*}{ Sample } & \multicolumn{2}{|c|}{$\%$ Atomic } & \multirow{2}{*}{$\mathrm{S} / \mathrm{Fe}$} & \multirow{2}{*}{ Formula } & \multirow{2}{*}{$\begin{array}{l}\text { Type of } \\
\text { Sulphide }\end{array}$} & \multirow{2}{*}{ Other elements } \\
\hline & $\mathrm{Fe}$ & $s$ & & & & \\
\hline Lame A & 4.65 & 9.22 & 2 & $\mathrm{FeS}_{2}$ & Pyrite & $\mathrm{Na}+\mathrm{Al}+\mathrm{C}$ \\
\hline Lame A & 4.03 & 9.55 & 2.4 & $\mathrm{FeS}_{2}$ & Pyrite & $\mathrm{Ca}$ \\
\hline Lame A & 5.48 & 9.73 & 1.8 & $\mathrm{FeS}_{2}$ & Pyrite & $\mathrm{C}$ \\
\hline Lame A & 5.67 & 2.78 & 0.5 & - & - & $\mathrm{C}+\mathrm{Al}+\mathrm{Ca}$ \\
\hline Lame A & 5.78 & 10.51 & 1.8 & $\mathrm{FeS}_{2}$ & Pyrite & $\mathrm{C}$ \\
\hline Lame A & 5.49 & 10.75 & 2 & $\mathrm{FeS}_{2}$ & Pyrite & $\mathrm{C}$ \\
\hline Lame A & 3.57 & 8.43 & 2.4 & $\mathrm{FeS}_{2}$ & Pyrite & $\mathrm{C}+\mathrm{Na}+\mathrm{Al}+\mathrm{Dy}$ \\
\hline Lame A & 5.75 & 10.21 & 1.8 & $\mathrm{FeS}_{2}$ & Pyrite & $\mathrm{C}+\mathrm{Na}+\mathrm{Al}+\mathrm{Ca}$ \\
\hline Lame A & 3.8 & 8.95 & 2.4 & $\mathrm{FeS}_{2}$ & Pyrite & $\mathrm{C}$ \\
\hline Lame A & 5.35 & 10.35 & 1.9 & $\mathrm{FeS}_{2}$ & Pyrite & $\mathrm{C}$ \\
\hline Lame A & 4.67 & 9.51 & 2 & $\mathrm{FeS}_{2}$ & Pyrite & $\mathrm{C}$ \\
\hline Lame A & 0.99 & 1.7 & 1.7 & $\mathrm{CuFeS}_{2}$ & Chalcopyrite & $\mathrm{C}+\mathrm{Na}+\mathrm{Al}+\mathrm{Cu}+\mathrm{Zn}+\mathrm{Ta}$ \\
\hline Lame A & 1.75 & 3.49 & 2 & $\mathrm{FeS}_{2}$ & Pyrite & $\mathrm{C}+\mathrm{Na}+\mathrm{Al}+\mathrm{Ca}+\mathrm{K}$ \\
\hline Lame A & 2.35 & 4.67 & 2 & $\mathrm{FeS}_{2}$ & Pyrite & $\mathrm{C}+\mathrm{Al}+\mathrm{Dy}$ \\
\hline Lame A & 4.59 & 8.18 & 1.8 & $\mathrm{FeS}_{2}$ & Pyrite & $\mathrm{C}+\mathrm{Na}+\mathrm{Al}+\mathrm{K}$ \\
\hline Lame A & 6.5 & 10.57 & 1.6 & $\mathrm{FeS}_{2}$ & Pyrite & $\mathrm{C}+\mathrm{Na}+\mathrm{K}+\mathrm{Dy}$ \\
\hline Lame A & 5.33 & 9.55 & 1.8 & $\mathrm{FeS}_{2}$ & Pyrite & $\mathrm{C}$ \\
\hline Lame A & 4.59 & 9.24 & 2 & $\mathrm{FeS}_{2}$ & Pyrite & $\mathrm{C}$ \\
\hline Lame A & 3.78 & 8.93 & 2.4 & $\mathrm{FeS}_{2}$ & Pyrite & $\mathrm{C}+\mathrm{Na}+\mathrm{Al}+\mathrm{Ca}+\mathrm{Dy}$ \\
\hline Lame A & 5.38 & 6.13 & 1.1 & $\mathrm{FeS}$ & Pyrrhotite & $\mathrm{C}+\mathrm{Na}$ \\
\hline Lame B-1 & 6.68 & 7.56 & 1.1 & $\mathrm{FeS}$ & Pyrrhotite & $\mathrm{C}$ \\
\hline Lame B-1 & 5.91 & 6.74 & 1.1 & $\mathrm{FeS}$ & Pyrrhotite & $\mathrm{C}+\mathrm{Al}+\mathrm{Ca}+\mathrm{Dy}$ \\
\hline Lame B-1 & 7.31 & 7.63 & 1 & $\mathrm{FeS}$ & Pyrrhotite & $\mathrm{C}+\mathrm{Fr}$ \\
\hline Lame B-1 & 7.66 & 9.39 & 1.2 & $\mathrm{FeS}$ & Pyrrhotite & $C+K$ \\
\hline Lame B-1 & 9.46 & 7.34 & 0.8 & $\mathrm{FeS}$ & Pyrrhotite & C \\
\hline Lame B-1 & 7.36 & 8.1 & 1.1 & $\mathrm{FeS}$ & Pyrrhotite & C \\
\hline Lame B-1 & 5.35 & 9.97 & 1.9 & $\mathrm{FeS}_{2}$ & Pyrite & $\mathrm{C}+\mathrm{Na}$ \\
\hline Lame B-1 & 8.49 & 7.87 & 0.9 & $\mathrm{FeS}$ & Pyrrhotite & $C+D y$ \\
\hline Lame B-1 & 7.49 & 7.99 & 1.1 & $\mathrm{FeS}$ & Pyrrhotite & C \\
\hline Lame B-1 & 8.06 & 6.64 & 0.8 & $\mathrm{FeS}$ & Pyrrhotite & $\mathrm{C}+\mathrm{Ca}$ \\
\hline Lame B-1 & 8.83 & 7.57 & 0.9 & $\mathrm{FeS}$ & Pyrrhotite & $\mathrm{C}$ \\
\hline
\end{tabular}




\section{Continued}

\begin{tabular}{|c|c|c|c|c|c|c|}
\hline Lame B-1 & 15.33 & 12.32 & 0.8 & $\mathrm{FeS}$ & Pyrrhotite & $\mathrm{C}$ \\
\hline Lame B-1 & 12.79 & 6.27 & 0.5 & - & Chalcopyrite? & $\mathrm{C}+\mathrm{Cu}+\mathrm{Dy}$ \\
\hline Lame B-2 & 5.32 & 7.97 & 1.5 & $\mathrm{FeS}_{2}$ & Pyrite & $\mathrm{C}$ \\
\hline Lame B-2 & 7.19 & 6.87 & 1 & $\mathrm{FeS}$ & Pyrrhotite & $\mathrm{C}+\mathrm{Ca}+\mathrm{Dy}$ \\
\hline Lame B-2 & 3.39 & 6.12 & 1.8 & $\mathrm{FeS}_{2}$ & Pyrite & $\mathrm{C}+\mathrm{Na}+\mathrm{K}$ \\
\hline Lame B-2 & 12.16 & 6.58 & 0.5 & - & - & $\mathrm{C}+\mathrm{Al}$ \\
\hline Lame B-2 & 4.06 & 7.24 & 1.8 & $\mathrm{FeS}_{2}$ & Pyrite & $\mathrm{C}+\mathrm{Na}+\mathrm{Dy}$ \\
\hline Lame B-2 & 4.46 & 8.41 & 1.9 & $\mathrm{FeS}_{2}$ & Pyrite & $\mathrm{C}$ \\
\hline Lame B-2 & 3.36 & 0.15 & 0 & - & - & $\mathrm{C}+\mathrm{Mg}+\mathrm{Al}+\mathrm{K}$ \\
\hline Lame B-2 & 4.3 & 6.96 & 1.6 & $\mathrm{FeS}_{2}$ & Pyrite & $\mathrm{C}+\mathrm{Na}+\mathrm{Al}+\mathrm{Dy}$ \\
\hline Lame B-2 & 7.14 & 7.4 & 1 & $\mathrm{FeS}$ & Pyrrhotite & $\mathrm{C}$ \\
\hline Lame B-2 & 6.02 & 5.05 & 0.8 & $\mathrm{FeS}$ & Pyrrhotite & $\mathrm{C}+\mathrm{Al}+\mathrm{Dy}$ \\
\hline Lame B-2 & 4.88 & 7.35 & 1.5 & $\mathrm{FeS}_{2}$ & Pyrite & $\mathrm{C}+\mathrm{Al}$ \\
\hline Lame B-2 & 4.78 & 6.88 & 1.4 & $\mathrm{FeS}_{2}$ & Pyrite & $\mathrm{C}+\mathrm{Na}+\mathrm{Al}+\mathrm{K}$ \\
\hline Lame B-2 & 3.31 & 6.85 & 2.1 & $\mathrm{FeS}_{2}$ & Pyrite & $\mathrm{C}+\mathrm{Al}+\mathrm{K}$ \\
\hline Lame C-1 & 5.32 & 10.11 & 1.9 & $\mathrm{FeS}_{2}$ & Pyrite & $\mathrm{C}$ \\
\hline Lame C-1 & 4.68 & 8.43 & 1.8 & $\mathrm{FeS}_{2}$ & Pyrite & $\mathrm{C}+\mathrm{Na}+\mathrm{K}+\mathrm{Dy}$ \\
\hline Lame C-1 & 5.23 & 10.56 & 2 & $\mathrm{FeS}_{2}$ & Pyrite & $\mathrm{C}$ \\
\hline Lame C-1 & 3.88 & 6.91 & 1.8 & $\mathrm{FeS}_{2}$ & Pyrite & $\mathrm{C}+\mathrm{Na}+\mathrm{Al}$ \\
\hline Lame C-1 & 8.11 & 9.26 & 1.1 & $\mathrm{FeS}$ & Pyrrhotite & $\mathrm{C}$ \\
\hline Lame C-2 & 5.68 & 9.69 & 1.7 & $\mathrm{FeS}_{2}$ & Pyrite & $\mathrm{C}$ \\
\hline Lame C-2 & 3.81 & 8.55 & 2.2 & $\mathrm{FeS}_{2}$ & Pyrite & $\mathrm{C}$ \\
\hline Lame C-2 & 4.77 & 8.79 & 1.8 & $\mathrm{FeS}_{2}$ & Pyrite & $\mathrm{C}+\mathrm{Na}+\mathrm{K}+\mathrm{Dy}$ \\
\hline Lame C-2 & 4.37 & 8.84 & 2 & $\mathrm{FeS}_{2}$ & Pyrite & $\mathrm{C}+\mathrm{Na}+\mathrm{Ca}$ \\
\hline Lame C-2 & 4.36 & 8.42 & 1.9 & $\mathrm{FeS}_{2}$ & Pyrite & $\mathrm{C}+\mathrm{Na}+\mathrm{K}+\mathrm{Zr}$ \\
\hline Lame E & 4.97 & 9.52 & 1.9 & $\mathrm{FeS}_{2}$ & Pyrite & $\mathrm{C}+\mathrm{K}$ \\
\hline Lame E & 4.6 & 9.75 & 2.1 & $\mathrm{FeS}_{2}$ & Pyrite & $\mathrm{C}$ \\
\hline Lame E & 5.08 & 10.28 & 2 & $\mathrm{FeS}_{2}$ & Pyrite & $\mathrm{C}$ \\
\hline Lame E & 9.91 & 9.49 & 1 & $\mathrm{FeS}$ & Pyrrhotite & $\mathrm{C}+\mathrm{Na}+\mathrm{K}$ \\
\hline Lame E & 4.06 & 8.85 & 2.2 & $\mathrm{FeS}_{2}$ & Pyrite & $\mathrm{C}+\mathrm{Ca}$ \\
\hline Lame E & 4.9 & 8.73 & 1.8 & $\mathrm{FeS}_{2}$ & Pyrite & $\mathrm{C}+\mathrm{Na}+\mathrm{Mg}+\mathrm{Al}$ \\
\hline Lame E & 4.63 & 8.66 & 1.9 & $\mathrm{FeS}_{2}$ & Pyrite & $\mathrm{C}+\mathrm{Si}+\mathrm{K}$ \\
\hline Lame E & 2.65 & 1.37 & 0.5 & - & - & $\mathrm{C}+\mathrm{Mg}+\mathrm{Al}+\mathrm{K}+\mathrm{Ca}$ \\
\hline Lame E & 6.17 & 8.09 & 1.3 & $\mathrm{FeS}$ & Pyrrhotite & $\mathrm{C}$ \\
\hline Lame E & 5.29 & 9.78 & 1.8 & $\mathrm{FeS}_{2}$ & Pyrite & $\mathrm{C}$ \\
\hline Lame E & 4.51 & 8.72 & 1.9 & $\mathrm{FeS}_{2}$ & Pyrite & $\mathrm{C}+\mathrm{Al}$ \\
\hline
\end{tabular}



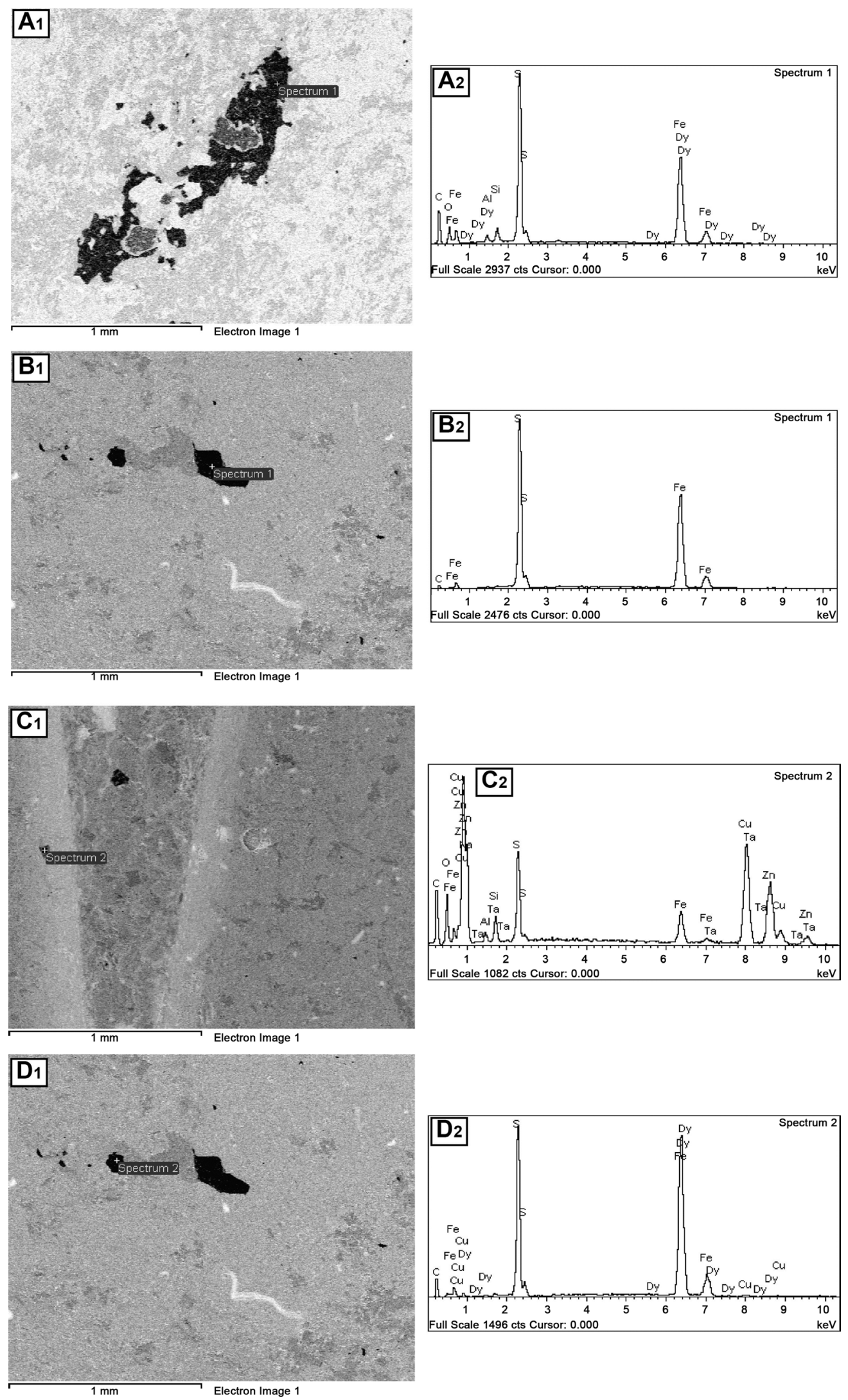

Figure 10. Microscopic aspects of pyrrhotite and chalcopyrite seen with SEM with their spectrum (this work). (A) and (B) Pyrrhotite; (C) and (D) Chalcopyrite. 


\subsection{Does the Mineralization at Tondabo Present a Lithological Control?}

Study of the Tondabo prospect revealed that gold mineralization is mainly associated with acid dykes (rhyodacites). The mineralization in mafic volcanics (volcanic lavas and volcanoclastites) is linked to areas of strong deformation and/or the contact with felsic and presents only low powers. This lithological control shows gold and sulphide mineralization in a typical form. Although sometimes, the disseminated mineralization that could suggest a syngenetic type, the mineralization at Tondabo remains overall vein mineralization supported by a network of veins forming stockworks. This suggests an epigenetic evidence of the mineralization.

At Tondabo, the highest grades are found in areas rich in quartz veins; enrichment mainly due to shear zones. Mineralization is, in addition to sulphides, associated with carbonation, sericitization and silicification in majority; and in the minority in chloritization, epididization and hematization.

This type of mineralization has already been mentioned in most of the Birimian deposits in Côte d'Ivoire (Aféma: [7] [8]; Angovia: [9]; Bonikro: [10]; Tongon: [11]) and West Africa [12] [13] [14] [15].

\subsection{Does the Mineralization at Tondabo Have Structural Control?}

In the Tondabo prospect, the diamond drilling survey shows that the host rocks of the mineralization are very deformed and generally affected by a foliation oriented mainly N000- $010^{\circ}$ and minority N040-050 $80^{\circ}$ towards the West. Indeed, the foliation observed could be linked to the general NW-SE compression-transpression phase which allowed the establishment of large NE-SW structures. A second deformation phase can be observed in the mineralized zones through hydrothermal brecciation and the stockworks in zones with strong silicification. The reference [16] defines a structural control in the Tabakoroni and Tellem deposits (in Mali) where, according to this author, mineralization is concentrated in the formations where the brittle deformation structures are the most developed.

This brittle deformation controlling the mineralization was also highlighted in the Morila belt in Mali [17], where the enrichment is linked to the Bannifin shear zone. This structural control of gold mineralization has also been recognized on the distribution of gold mineralization in the Kedougou-Kenieba inlier [17] [18] [19]; in the Ashanti belt in Ghana [20] [21] [22]; in the Sabodala gold shear zones in Senegal [23]; Taparko [24] and Diabatou [12] [13] [25] in Burkina Faso; Abawso [26] in Ghana; Bonikro [1], Agbahou [2], Bandama-Dougbafla [3], Bobosso [27] and Yaouré [28] in Côte d'Ivoire.

\subsection{What Are the Alterations Associated with the Tondabo Mineralization and Its Metalliferous Paragenesis?}

The most common alterations in the mineralized zone are pervasive carbonation and silification which intensify near shear zones. This strong silicification is an 
alteration manifested by the filling of fractures with hydrothermal fluids enriched in metals which always accompany gold mineralization. The metalliferous paragenesis is mainly composed of pyrite and incidentally pyrrhotite and chalcopyrite which remain associated with gold. The Tondabo gold mineralization is similar to the Syama deposit in the Bagoé belt [16] both in terms of metalliferous association (abundant pyrite) and in style of mineralization (stockworks of carbonates and quartz veins). However, it remains different from the Tabakoroni deposit where the dominant sulphides are arsenopyrite and pyrite.

In Côte d'Ivoire, compared to the deposits in the southern part of the OuméToumodi-Fettêkro greenstone belt of Bonikro [1], Agbahou [2] and BandamaDougbafla [3], the metalliferous paragenesis of Tondabo remains the same but is differentiated by the absence of arsenopyrite and molybdenite.

\section{Conclusion}

The gold mineralization of the Tondabo prospect is hosted mainly by the rhyodacites and to a lesser extent by the mafic volcanics (volcanic lavas and volcanoclastites). These rocks were affected by a hydrothermal alteration marked by quartz veins and veinlets associated with crystals of carbonates, sericite, epidote and sulfides. This hydrothermal alteration induced a pervasive alteration of the surrounding bodies with chloritization, carbonation and sericitization of the feldspar. Indeed, it is mainly affected by carbonation (calcite, dolomite), sericitization and silicification; and in the minority by chloritization, epididization and hematization. This mineralization, located mainly in the rhyodacite, indicates that the Tondabo gold prospect has lithological control. The mineralized deposits are generally affected by a S1 foliation oriented mainly N000- $010^{\circ}$ and minority N040- $050^{\circ}$ with a general dip of $60^{\circ}-80^{\circ}$ to the West; however with rare N-S orientations with a dip of $60^{\circ}-80^{\circ}$ to the East. The intervals of holes showing the highest gold contents are linked to the quartz veins and veinlets, which are located in highly deformed zones. These veins are of three types which are chronologically: 1) the transverse veins which crosscut the foliation; 2) the planar veins subparallel to each other and to the schistosity, sometimes having a sausage; and 3) the late planar veins, which crosscut the whole. The Tondabo gold prospect exhibits structural control. The metalliferous paragenesis consists of pyrite (main sulfide), pyrrhotite and rarely chalcopyrite. We note in this prospect a first phase of disseminated pyritization, which seems to be contemporary with regional foliation. The second phase of pyritization is recent, and associated to quartz veins associated with sericite-carbonates crystals which would have favored mineralization.

\section{Acknowledgements}

This paper was initiated as part of the thesis researches by the author DBSM in the Brobo region. Some data have been authorized by certain companies. Thus, we would like to thank LGL Resources CI SA who carried out the initial works. 
Our thanks go to Mr. Jean-Paul Bout, Director of LGL Resources CI and Mr. Paul Kito, Director of Newcrest Exploration CI who made additional works in the study area.

\section{Conflicts of Interest}

The authors declare no conflicts of interest regarding the publication of this paper.

\section{References}

[1] Ouattara, Z. (2015) Caractères lithostratigraphiqie, structural, géochimique et métallogénique du gisement d'or de Bonikro, sillon birimien de Fettekro, centre-sud de la Côte d'Ivoire. Doctorat, Université Félix Houphouët-Boigny, 256 p.

[2] Houssou, N.N. (2013) Etude pétrologique, structurale et métallogénique du gisement aurifère d'Agbahou, Divo, Côte d'Ivoire. Doctorat, Université Félix Houphouët-Boigny, $177 \mathrm{p}$.

[3] Ouattara, A.S. (2018) Le gisement aurifère de Dougbafla-Bandama (Sud du sillon birimien de Fettékro, Oumé, Côte d'Ivoire): Pétrographie, déformation, géochimie et métallogénie. Doctorat, Université Félix Houphouët-Boigny, 313 p.

[4] Yao, D.B. (1988) Carte géologique de Côte d'Ivoire, feuille de M'Bahiakro à 1/200 000. Ministère des Mines, Direction de la Géologie.

[5] Daï-Bi, S.M., Ouattara, G., Koffi, G.B., Ganzou, A. and Coulibaly, I. (2018) Mise en évidence de nouvelles structures géologiques dans la région de Brobo (Centre de la Côte d'Ivoire). Aide à la compréhension de la tectonique du Paléoprotérozoïque du Craton Ouest Africain. European Scientific Journal, 14, 305-324.

https://doi.org/10.19044/esj.2018.v14n18p305

[6] Newcrest Mining Limited (2013) CDI Greenfields Exploration Report. Côte d'Ivoire, May 2013 (Reporting Period 26/04 to 25/05), 47 p.

[7] Assié, K.E. (2008) Lode Gold Mineralization in the Paleoproterozoic (Birimian) Volcanosedimentary Sequence of Afema Gold District, Southeastern Côte d'Ivoire. Thesis, Faculty of Energy and Economic Sciences Technical University of Clausthal, Germany, 198 p.

[8] Kadio, E., Coulibaly, Y., Allialy, M.E., Kouamelan, A.N. and Pothin, K.B.K. (2010) On the Occurrence of Gold Mineralization's in Southeastern Ivory Coast. Journal of African Earth Sciences, 57, 423-430. https://doi.org/10.1016/j.jafrearsci.2009.11.008

[9] Coulibaly, Y., Boiron, M.C., Cathelineau, M. and Kouamelan, A.N. (2008) Fluid Immiscibility and Gold Deposition in the Birimian Quartz Veins of the Angovia Deposit (Yaouré, Ivory Coast). Journal of African Earth Sciences, 50, 234-254. https://doi.org/10.1016/j.jafrearsci.2007.09.014

[10] Gnanzou, A. (2006) Etude lithostratigraphique de la région de Hiré dans le centre-sud de la Côte d'Ivoire (Permis de recherche PRA 37): Implication à la connaissance de la minéralisation aurifère. DEA, UFR-STRM, Université Félix Houphouët-Boigny d'Abidjan, 60 p.

[11] Randgold Resources Ltd (2001) Permis de Niellé. Rapport Final, 90 p.

[12] Milési, J.P., Feybesse, J.L., Ledru, P., Dommanget, A., Ouédraogo, M.F., Marcoux, E., Prost, A.E., Vinchon, C., Sylvain, J.P., Johan, V., Tegyey, M., Calvez, J.Y. and Lagny, P. (1989) Les minéralisations aurifères de l'Afrique de l'Ouest. Leurs relations avec l'évolution lithostructurale au Protérozoïque inférieur. Chronique de la Recherche Minière, 497, 3-98. 
[13] Milesi, J.P., Ledru, P., Feybesse, J.L., Dommanget, A. and Marcoux, E. (1992) Early Proterozoïc ore Deposits and Tectonics of the Birimian Orogenic Belt, West Africa. Precambrian Research, 58, 305-344. https://doi.org/10.1016/0301-9268(92)90123-6

[14] Block, S., Ganne, J., Baratoux, L., Zeh, A., Parra-Avila, L.A., Jessel, M., Ailleres, L. and Siebenaller, L. (2015) Petrological and Geochronological Constraints on Lower Crust Exhumation during Paleoproterozoic (Eburnean) Orogeny, NW Ghana, West African Craton. Journal of Metamorphic Geology, 33, 463-494.

https://doi:10.1111/jmg.12129

[15] Treloar, P.J., Lawrence, D.M., Senghor, D., Boyce, A. and Harbidge, P. (2015) The Massawa Gold Deposit, Eastern Senegal, West Africa: An Orogenic Gold Deposit Sourced from Magmatically Derived Fluids? Ore Deposits in an Evolving Earth. Geological Society, London, Special Publications, 393, 135-160. http://dx.doi.org/10.1144/SP393.12

[16] Traore, D.Y. (2017) Etude métallogénique du district aurifère de Syama (Mali): analyse comparative de gisements situés sur une même structure lithosphérique éburnéenne. Géologie appliquée. Université Toulouse 3 Paul Sabatier (UT3 Paul Sabatier), France, 295 p.

[17] Lawrence, D.M., Lambert-Smith, J.S. and Treloar, P.J. (2016) A Review of Gold Mineralization in Mali. In: Bouabdellah, M. and Slack, J. eds., Mineral Deposits of North Africa, Mineral Resource Reviews, Springer, Cham, 327-351. https://doi.org/10.1007/978-3-319-31733-5_13

[18] Masurel, Q. (2016) 4D Evolution of the Sadiola-Yatela Gold District, KédougouKéniéba Inlier, West Africa. PhD Thesis, The University of Western Australia, 248 p.

[19] Masurel, Q., Thébaud, N., Miller, J., Ulrich, S., Hein, K.A.A., Cameron, G., Béziat, D., Bruguier, O. and Davis, J.A. (2016) Sadiola Hill: A World-Class CarbonateHosted Gold Deposit in Mali, West Africa. Economic Geology, 112, 23-47. https://doi.org/10.2113/econgeo.112.1.23

[20] Oberthür, T., Schmidt, M.A., Vetter, U., Simon, K. and Amanor, J.A. (1996) Gold Mineralization in the Ashanti Belt of Ghana: Genetic Constraints of the Stable Isotope Geochemistry. Economic Geology, 91, 289-301. https://doi.org/10.2113/gsecongeo.91.2.289

[21] Oberthür, T., Weiser, T. and Amanor, J.A. (1997) Mineralogical Sitting and Distribution of Gold in Quartz Veins and Sulphide Ores of the Ashanti Mine and Other Deposits in the Ashanti Belt of Ghana: Genetic Implications. Mineralium Deposita, 32, 2-15. https://doi.org/10.1007/s001260050068

[22] Perrouty, S, Aillères, L, Jessell, M, Baratoux, L, Bourassa, Y. and Crawford, B. (2012) Revised Eburnean Geodynamic Evolution of the Gold-Rich Southern Ashanti Belt, Ghana, with New Field and Geophysical Evidence of Pre-Tarkwaian Deformations. Precambrian Research, 204-205, 12-39. https://doi.org/10.1016/j.precamres.2012.01.003

[23] Sylla, M. and N’Gom, P.M. (1997) Le gisement d'or de Sabodala (Sénégal Oriental): une minéralisation filonienne d'origine hydrothermale remobilisée par une tectonique cisaillante. Journal of African Earth Sciences, 25, 183-192. https://doi.org/10.1016/S0899-5362(97)00097-3

[24] Bourges, F., Débat, P., Tollon, F., Munoz, M. and Ingles, J. (1998) The Geology of the Taparko Gold Deposit, Birimian Greenstone Belt, Burkina Faso, West Africa. Mineral Deposita, 33, 591-605. https://doi.org/10.1007/s001260050175

[25] Klemd, R. and Ott, S. (1997) Compositional Characteristics of Fluid Inclusions as 
Exploration Tool for Au-Mineralization at Larafella, Burkina Faso. Journal of Geochemical Exploration, 59, 251-258.

https://doi.org/10.1016/S0375-6742(97)00012-5

[26] Wille, S.E. and Klemd, R. (2004) Fluid Inclusion Studies of the Abawso Gold Prospect, Near the Ashanti Belt, Ghana. Mineralium Deposita, 39, 31-45.

https://doi.org/10.1007/s00126-003-0380-1

[27] Gnanzou, A. (2014) Etude des séries volcano-sédimentaires de la région de Dabakala (Nord-Est de la Côte d'Ivoire): genèse et évolution magmatique. Contribution à la connaissance de la minéralisation aurifère de Bobosso dans la série de la Haute-Comoé. Thèse de Doctorat, Université Paris-Saclay, France et Université Félix HouphouëtBoigny, $303 \mathrm{p}$.

[28] Mériaud, N., Masurel, Q., Thébaud, N. and Tourigny, G. (2019) Fluid PressureDominated Orogenic Gold Mineralization under Low Differential Stress: Case of the Yaouré Gold Camp, Côte d'Ivoire, West Africa. Mineralium Deposita, 18 p. https://doi.org/10.1007/s00126-019-00927-y 